\title{
Kisspeptin Activates Ankrd 26 Gene Expression in Migrating Embryonic GnRH Neurons
}

\author{
Tomoko Soga', Wei Ling Lim ${ }^{1}$, Alan Soo-Beng Khoo ${ }^{2}$ and Ishwar S. Parhar ${ }^{1 *}$ \\ ${ }^{1}$ Brain Research Institute, School of Medicine and Health Sciences, Monash University Malaysia, Bandar Sunway, Malaysia, \\ ${ }^{2}$ Molecular Pathology Unit, Cancer Research Centre, Institute for Medical Research, Kuala Lumpur, Malaysia
}

\section{OPEN ACCESS}

Edited by:

Sebastien G. Bouret,

University of Southern California, USA

Reviewed by:

Paolo Giacobini,

University of Lille, France

Philippe Ciofi,

Institut National de la Santé et de la

Recherche Médicale, France

*Correspondence:

Ishwar S. Parhar

ishwar@monash.edu

Specialty section:

This article was submitted to

Neuroendocrine Science,

a section of the journal

Frontiers in Endocrinology

Received: 03 November 2015

Accepted: 28 January 2016

Published: 01 March 2016

Citation:

Soga T, Lim WL, Khoo AS-B and Parhar IS (2016) Kisspeptin Activates

Ankrd 26 Gene Expression in Migrating Embryonic GnRH Neurons.

Front. Endocrinol. 7:15.

doi: 10.3389/fendo.2016.00015
Kisspeptin, a newly discovered neuropeptide, regulates gonadotropin-releasing hormone $(\mathrm{GnRH})$. Kisspeptins are a large RF-amide family of peptides. The kisspeptin coded by KiSS-1 gene is a 145-amino acid protein that is cleaved to C-terminal peptide kisspeptin-10. G-protein-coupled receptor 54 (GPR54) has been identified as a kisspeptin receptor, and it is expressed in $\mathrm{GnRH}$ neurons and in a variety of cancer cells. In this study, enhanced green fluorescent protein (EGFP) labeled GnRH cells with migratory properties, which express GPR54, served as a model to study the effects of kisspeptin on cell migration. We monitored EGFP-GnRH neuronal migration in brain slide culture of embryonic day 14 transgenic rat by live cell imaging system and studied the effects of kisspeptin-10 (1 nM) treatment for $36 \mathrm{~h}$ on $\mathrm{GnRH}$ migration. Furthermore, to determine kisspeptin-induced molecular pathways related with apoptosis and cytoskeletal changes during neuronal migration, we studied the expression levels of candidate genes in laser-captured EGFP-GnRH neurons by real-time PCR. We found that there was no change in the expression level of genes related to cell proliferation and apoptosis. The expression of ankyrin repeat domain-containing protein (ankrd) 26 in EGFP-GnRH neurons was upregulated by the exposure to kisspeptin. These studies suggest that ankrd 26 gene plays an unidentified role in regulating neuronal movement mediated by kisspeptin-GPR54 signaling, which could be a potential pathway to suppress cell migration.

Keywords: metastasis, cancer, cytoskeleton, preoptic area, reproduction, GPR54

\section{INTRODUCTION}

Kisspeptin is a newly discovered neuropeptide that controls the onset of puberty and stimulates gonadotropin-releasing hormone $(\mathrm{GnRH})$ release from the preoptic area (POA). Kisspeptin encoded by KiSS-1 gene is a 145-amino acid peptide. The primary translation products are shorter, biologically active cleavage neuropeptides, kisspeptin-54, $-14,-13,-10$ amino acid residues, which are endogenous ligands for G-protein-coupled receptor 54 (GPR54) (1-3). Kisspeptin-GPR54 signaling is coupled with $\mathrm{Gq} / 11(1,2)$. Intracellular kisspeptin-GPR54 pathway activates $\mathrm{Ca}^{2+}$-dependent signals, such as $\mathrm{Ca}^{2+}$ mobilization and phosphorylated by mitogen-activated protein kinases (1). Kisspeptin synthesizing neurons are localized in the hypothalamus, but expression of kisspeptin and GPR54 is also found in various peripheral tissue, such as the placenta, pancreas, the testes (3-5), and notably, GPR54 is expressed in metastatic human cancer cell lines (6). 
Reproductive neuropeptide, GnRH stimulates the secretion of pituitary gonadotropins and activates release of gonadal hormones to control reproductive activity. Interestingly, $\mathrm{GnRH}$ neurons have a unique developmental process. Embryonic $\mathrm{GnRH}$ neurons have high degree of motility; they originate from the olfactory placodes and migrate into the POA, their final residing place in the brain of all vertebrates (7-10). In rats, GnRH neurons actively start to migrate from the olfactory placodes on embryonic day 13.5 (E13.5) (11) and reach their final position in the POA on E18-19 (12). Approximately 1500 GnRH neurons are observed during early developmental stages, and these remain unchanged in numbers in the POA during adult stages $(11,12)$. Abnormal development of GnRH neurons, such as failed embryonic migration, altered numbers or positioning in the POA causes hypogonadotropic hypogonadism and reproductive dysfunction $(13,14)$.

Although kisspeptin-GPR54 signaling in GnRH neurons is well demonstrated as a key component for the onset of puberty (15-18), GnRH neurons express GPR54 before pubertal onset and kisspeptin-GPR54 system are established in embryonic mice brain $(19,20)$. In addition, recent study suggests that neuronal connection of kisspeptin neurons in the arcuate nucleus and a specific subgroup of GnRH neurons are established during embryonic stage in mice brain (21). An important role in controlling reproduction is emblematic of kisspeptin's biological functions (22); however, this peptide is multifunctional $(5,23)$. The peptide has been shown to regulate cognitive functions, such as anxiety, learning, and memory (24-26), and as a metastasis suppressor (Metastin = Kisspeptin 54) (2). There are no studies describing the function of kisspeptin-GPR54 cellular signaling in normal migrating GnRH cells in the developing brain. However, an earlier study had suggested the possibility of GPR54 as a "stop molecule" for GnRH neuronal migration in the brain of a teleost fish (27).

Several studies have shown that kisspeptin is involved in cancer cell invasion (28-30), cell migration $(2-4,6)$, cell cycle arrest, and induction of cancer cell apoptosis (31). The cellular mechanisms of kisspeptin's inhibitory effect on cell invasion, migration, cell cycle arrest, or induction of apoptosis have been suggested to be via altered cell motility and adhesiveness (32).

As accumulating evidences of kisspeptin neurons and GPR54 expression in early developmental stage, it is possible that kisspeptin-GRP54 signaling may be functionally involved in embryonic migrating GnRH neurons long before puberty and reproductive maturate stage. This study was designed to determine whether kisspeptin-10 could influence embryonic GnRH neuronal migration, which could be important in the understanding of the mechanisms of neuronal migration. Here, we report that kisspeptin-10 activates ankrd26 gene expression in migrating embryonic GnRH neurons and inhibits their ability to migrate.

\section{MATERIALS AND METHODS}

\section{Animals}

Transgenic Wistar rats expressing the enhanced green fluorescent protein (EGFP) under control of the rat GnRH promoter (33) were used to enable the direct visualization of $\mathrm{GnRH}$ neurons. The rats were housed as groups (2-3/cage) under a 12-h light cycle (lights on from 12:00 a.m. to 12:00 p.m.) and controlled temperature $\left(22.0 \pm 1.0^{\circ} \mathrm{C}\right)$ in the Specific Pathogen Free animal facility of the Brain Research Institute, Monash University Malaysia. Food and water were available ad libitum. All procedures were carried out in accordance to the Guidelines for the Care and Use of Animals by Monash University (SOBSB/MY/2007/29, MARP/2011/064).

\section{Dissection and Brain Slice Preparation}

Adult female rats were time-bred, with the presence of spermatozoa in vaginal smear designated as on day 0 of gestation (E0). Pregnant female rats on E14 were anesthetized with an intraperitoneal injection of ketamine xylazine $(4.5 \mathrm{mg} / \mathrm{kg} /$ body weight). The embryos were immediately removed from the uterus and placed on glass dish with cold $1 \times$ Krebs buffer $(126 \mathrm{mM} \mathrm{NaCl}$, $2.5 \mathrm{mM} \mathrm{KCl}, 2.5 \mathrm{mM} \mathrm{CaCl}_{2} 1.2 \mathrm{mM} \mathrm{NaH}_{2} \mathrm{PO}_{4}, 1.2 \mathrm{mM} \mathrm{MgCl}_{2}$, $25 \mathrm{mM} \mathrm{NaHCO}_{3}$, and $11 \mathrm{mM}$ D-glucose, $\mathrm{pH}$ 7.2, sterile filtered). The embryonic brains were dissected in the cold Krebs buffer and embedded in $6.0 \%$ low gelling temperature agarose (Type VII-A, Sigma, St Louis, MO, USA) to harden on ice. The embedded brains were trimmed, glued with cyanoacrlylate (Loctite 404, Henkel Corporation, Rocky Hill, CT, USA) to the stage of vibratome (Vibratome 3000 Sectioning System, St. Louis, MO, USA), and sagittally sectioned at $300 \mu \mathrm{m}$ thickness in cold Krebs buffer. The slices were collected into glass-bottom dish filled with Krebs buffer supplemented with HEPES buffer solution (GIBCO-Invitrogen, Carlsbad, CA, USA), gentamicin reagent solution (GIBCO-Invitrogen), and antibiotic-antimycotic solution (GIBCO-Invitrogen). All sections were then incubated in medium [DMEM/F12 Phenol Red Free (GIBCO-Invitrogen), B-27 serum-free supplement (GIBCO-Invitrogen), L-glutamate, antibiotic-antimycotic solution, L-glutamine (Sigma), and D-glucose (Sigma)]. The sections were viewed under inverted fluorescence microscope (Nikon TE2000, Japan) for selection of brain slices containing EGFP-GnRH neurons.

\section{Embryonic Brain Slice Culture}

The embryonic brain slice selected for live cell imaging were adhered to the glass-bottom WillCo-dish (WillCo Wells BV, Amsterdam, Netherlands) using chicken plasma (10 $\mu$; Sigma) with thrombin $(25 \mu \mathrm{l}$; Sigma) (34) followed by $1.5 \mathrm{~h}$ incubation at $37^{\circ} \mathrm{C}$. After incubation, $1 \mathrm{ml}$ of culture medium [serumfree Neurobasal medium (GIBCO-Invitrogen) supplemented with B27, L-glutamine, antibiotic-antimycotic solution, and D-glucose] was added into the dish. Slices were maintained in culture medium at $37^{\circ} \mathrm{C}$, humidified with $5 \% \mathrm{CO}_{2}$ for $3 \mathrm{~h}$ to allow the slices to adhere to the glass coverslip and acclimatize to the culture condition (35) before imaging. For the exposure to kisspeptin, E14 embryonic slices were maintained in culture medium for 12-h post plating and kisspeptin-10 [1 nM, KiSS-1 (110-119) Amide, cat\# 048-65, Phoenix Pharmaceuticals, Inc., Burlingame, CA, USA] was added twice at $12 \mathrm{~h}$ interval for static incubation. Imaging of embryonic EGFP-GnRH neurons was continued for an additional $12 \mathrm{~h}$. Procedures for the brain slice culture and medium preparation were adapted from Bless et al. (36), with slight modifications to accommodate to the live cell imaging system. 


\section{Live Cell Imaging of Embryonic EGFP-GnRH Neurons}

The dish containing the attached E14 brain slice with culture medium was transferred into the chamber attached to the stage of Leica AF6000LX Live Cell Imaging System. The chamber temperature was maintained at $37^{\circ} \mathrm{C}$, humidified with $5 \% \mathrm{CO}_{2}$ (PeCon GmbH, Erbach, Germany). EGFP-GnRH neurons were visualized and captured under the $20 \times$ objective lens of the inverted fluorescence microscope. Time-lapse image analysis of the EGFP-GnRH neurons from E14 ( $n=6-13$ cells/time point) were expressed as the total distance traveled $(\mu \mathrm{m} / 12 \mathrm{~h})$ and the average rate of movement $(\mu \mathrm{m} / \mathrm{h})$ at $12 \mathrm{~h}$ interval for 36 h duration.

The exposure time, gain, and intensity parameters were kept constant during imaging A $z$-series of 25 images through the brain slice containing EGFP-GnRH neurons were collected every $4-5 \mu \mathrm{m}$ interval $(\sim 100-125 \mu \mathrm{m})$, at $5 \mathrm{~min}$ interval for total $36 \mathrm{~h}$ of video microscopy. The $z$-series of images collected were processed using the analysis software (Leica LAS AF) into projected stacks, and video images were generated for the analysis of GnRH neuronal migration. The live cell image of GnRH migration was captured wildly throughout the olfactory bulbs, junction area and ventral forebrain in the sagittal slice culture. All data of $\mathrm{GnRH}$ migration were averaged in each anatomical area in E14 developmental stage.

\section{Video Analysis}

Due to the long-term observation of $\mathrm{GnRH}$ neurons, images of the EGFP-GnRH neurons were collected every $5 \mathrm{~min}$ interval for 9,12 , or 15 h each session until 36 h of recording were completed. The video images were analyzed using Image Pro-Plus version 6.0 (Media Cybernetics Incorporation, Bethesda, MD, USA) to track movement of EGFP-GnRH neurons for absolute distance and velocity across the recording period. The absolute distance is defined as the distance traveled by the neurons captured at each frame in the video image sequence. The velocity generated by the software was calculated by dividing the duration of each frame $(5 \mathrm{~min}$ ) in the video sequence by the absolute distance traveled. Data for the embryonic EGFP-GnRH neuron migration were presented as total distance traveled and the average rate of neuronal movement at $12 \mathrm{~h}$ interval. Data from the video images of EGFP-GnRH neurons that showed notable tissue movement were discarded.

\section{Real-Time PCR for Laser-Captured Single EGFP-GnRH Cell}

After kisspeptin-10 treatment for $24 \mathrm{~h}$ (twice at $12 \mathrm{~h}$ interval), E14 embryonic brain slices were washed in $0.1 \mathrm{M}$ phosphate buffered saline (PBS) and fixed in 4\% paraformaldehyde (PFA) [buffered in $0.1 \mathrm{M}$ phosphate buffer $(\mathrm{PB})]$. The brain slices were re-cut in $14 \mu \mathrm{m}$, were pasted on APS-coated slides (Fisher Scientific), and were washed in diethylpyrocarbonate-treated water for $20 \mathrm{~s}$ (5 s dips). The protocol used for laser capture single EGFP-GnRH and real-time PCR was as described previously (37). The tissues were dehydrated in an ethanol series $(75 \% \mathrm{~V} / \mathrm{V}, 95 \% \mathrm{~V} / \mathrm{V}$, and $100 \%, 10 \mathrm{~s}$ each) and air dried. GnRH cells were dissected using a
UV laser component of Arcturus Laser Capture Microdissection System (Arcturus, Mountain View, CA, USA) powered at 31\%, slow speed cutting. The dissected cells (20-25 cells/animal) were pooled and collected into a microcentrifuge tube containing $200 \mu \mathrm{l}$ of chilled TBS using a micropipette attached to a micromanipulator (Narishige, Tokyo, Japan). The collected cells were precipitated by centrifugation at 3,000 rpm for $20 \mathrm{~min}$ at $4^{\circ} \mathrm{C}$ and the supernatant was discarded. The harvested cells were resuspended in $12.9 \mu \mathrm{l}$ of lysis buffer solution [7.9 $\mu \mathrm{l}$ of DEPC-treated water, $1.2 \mu \mathrm{l}$ of $10 \times$ first strand buffer, $1.2 \mu \mathrm{l}$ of $40 \%$ NP40, $0.6 \mu \mathrm{l}$ of Proteinase K $(1 \mathrm{mg} / \mathrm{ml})$, and $2 \mu \mathrm{l}$ of glycogen $(5 \mathrm{ng} / \mathrm{ml})]$ and incubated at $50^{\circ} \mathrm{C}$ for $20 \mathrm{~min}$, with mixing by vortexing at $10 \mathrm{~min}$ intervals. After inactivation of Proteinase $\mathrm{K}$ at $75^{\circ} \mathrm{C}$, the lysate was treated with $0.5 \mu \mathrm{l}$ of RQ1RNase-free DNase (Promega) at $37^{\circ} \mathrm{C}$ for $30 \mathrm{~min}$. DNase was then inactivated with $1.0 \mu \mathrm{l}$ of DNase stop solution (Promega) at $65^{\circ} \mathrm{C}$ for $10 \mathrm{~min}$. For reverse transcription, $0.4 \mu \mathrm{l}$ of DEPC-treated water, $0.8 \mu \mathrm{l}$ of $10 \times$ first strand buffer (Applied Biosystems), $0.8 \mu \mathrm{l}$ of $100 \mathrm{mM}$ dNTP, $2 \mu \mathrm{l}$ of $10 \times$ random primers, $0.6 \mu \mathrm{l}$ of RNase Inhibitor, and $1 \mu \mathrm{l}$ of Multiscribe reverse transcriptase (Applied Biosystems) were added. The reaction solution was incubated at $25^{\circ} \mathrm{C}$ for $10 \mathrm{~min}$, $37^{\circ} \mathrm{C}$ for $2 \mathrm{~h}$ and $85^{\circ} \mathrm{C}$ for $5 \mathrm{~min}$. RT-PCR for cyclophilin, gnrh, gfap (glial fibrillary acidic protein), gpr54, other target genes expression was carried out in a Mastercycler (Eppendorf, Germany) in a $10-\mu$ reaction volume comprising $1 \times$ PCR Gold Buffer (Applied Biosystems), $2.5 \mathrm{mM} \mathrm{MgCl}_{2}$ (Applied Biosystems), $0.2 \mathrm{mM}$ each dNTP (iDNA, Singapore), 0.25 U of AmpliTaq Gold A (Applied Biosystems), $0.25 \mu \mathrm{M}$ each forward and reverse primers (Table S1 in Supplementary Material), and $1 \mu \mathrm{l}$ of cDNA sample. PCR cycles were carried out under the following conditions: $95^{\circ} \mathrm{C}$ for $10 \mathrm{~min}, 40 \mathrm{cycles}$ of $95^{\circ} \mathrm{C}$ for $30 \mathrm{~s}, 60^{\circ} \mathrm{C}$ for $30 \mathrm{~s}$, and $72^{\circ} \mathrm{C}$ for $30 \mathrm{~s}$, with a final extension phase of $72^{\circ} \mathrm{C}$ for $5 \mathrm{~min}$. PCR products were electrophoresed on a $2.5 \%$ agarose gel, stained with ethidium bromide and visualized under an electronic UV transilluminator (ATTO, Bio-Instrument, Tokyo, Japan).

\section{Statistical Analysis}

All data are expressed as a mean \pm SEM for each group. Statistical analysis was carried out using PASW Statistics 18 (IBM SPSS Statistics; IBM, Chicago, IL, USA) software. The analysis of live cell imaging data was done using two-way repeated measure analysis of variance (ANOVA). The analysis of gene expression was done using $t$-test. Difference were considered significant when $p<0.05$.

\section{RESULTS}

\section{Migration of Embryonic EGFP-GnRH Neurons in the Brain}

The EGFP-GnRH neurons were identified by their fusiform morphology in the brain slice preparation of E14 rat brains (Figures 1A,B) and maintained in vitro for up to $36 \mathrm{~h}$ for time-lapse image analysis. The EGFP-GnRH neurons at E14 stage exhibited changes in their position (=were migrating) at different rates of motility within the brain slice during the $36 \mathrm{~h}$ of culture condition (Figure 1C). Time-lapse image analysis of 
the EGFP-GnRH neurons from E14 ( $n=6-13$ cells/time point) were expressed as the total distance traveled $(\mu \mathrm{m} / 12 \mathrm{~h})$ and the average rate of movement $(\mu \mathrm{m} / \mathrm{h})$ at $12 \mathrm{~h}$ interval for $36 \mathrm{~h}$ duration (Figure 2). The distance traveled by kisspeptin-10 exposed EGFP-GnRH neurons was significantly decreased at the 12-h culture time point [control, $158.2 \pm 27.5 \mu \mathrm{m}$, kisspeptin-10, $90.0 \pm 6.12 \mu \mathrm{m} ; t(11)=2.91 ; p<0.05]$. After 24 and $36 \mathrm{~h}$ of the
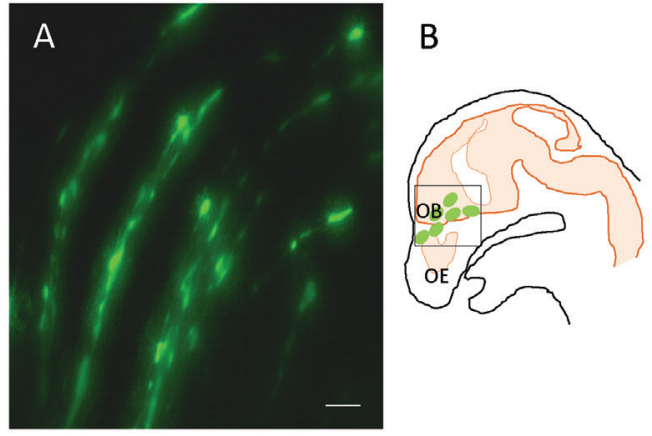

C

E14-GnRH Neurons

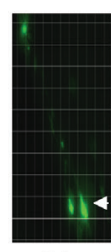

$\mathrm{O} \mathrm{hr}$

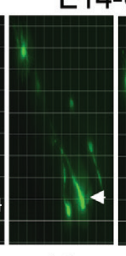

$3 \mathrm{hr}$

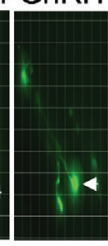

$6 \mathrm{hr}$ Time in vitro

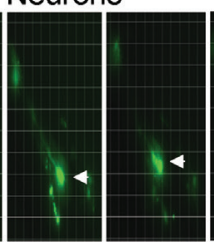

$9 \mathrm{hr} \quad 12 \mathrm{hr}$

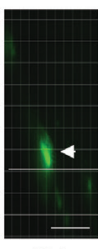

$15 \mathrm{hr}$
FIGURE 1 | Enhanced green fluorescent protein (EGFP)gonadotropin-releasing hormone $(\mathrm{GnRH})$ neurons on brain tissue in embryonic day 14 (E14) (A). Illustration of E14 rat sagittal head showing EGFP-GnRH neurons throughout olfactory bulb and ventral forebrain region and highlighted the area for live cell imaging (B). Images of migrating EGFP-GnRH neurons in brain tissue culture captured by live cell imaging system during $15 \mathrm{~h}$ in vitro (C). Scale bar $=50 \mu \mathrm{m}$ in $\mathbf{( A , C ) .}$ exposure to kisspeptin, the distance traveled by EGFP-GnRH cells was same as the control EGFP-GnRH neurons (Figure 2A). The average rate of movement of EGFP-GnRH cells was decreased in the 12-h culture time point for the exposure to kisspeptin [control $13.3 \pm 2.3 \mu \mathrm{m} / \mathrm{h}$, kisspeptin-10 exposed $7.6 \pm 0.46 \mu \mathrm{m} / \mathrm{h}$; $t(11)=2.43 ; p<0.05]$. The EGFP-GnRH neurons from the kisspeptin-10 exposed brain slice culture exhibited reduce motility compared to the control group maintained in vitro for $12 \mathrm{~h}$. But after $24 \mathrm{~h}$ and $36 \mathrm{~h}$ of the exposure to kisspeptin, the average rate of movement of the EGFP-GnRH cells was same as the control EGFP-GnRH neurons (Figure 2B).

\section{GPR54 Gene Transcripts in Embryonic EGFP-GnRH Neurons in the Brain}

To determine whether gpr54 gene transcripts are detected in embryonic EGFP-GnRH neurons, the expression of gpr54 gene in embryonic EGFP-GnRH neurons captured by laser dissection was measured using real-time PCR (Figures 3A,B). Gpr54 gene and egfp gene transcripts were detected in the laser-captured EGFP-GnRH neurons of E14 rat brains (Figure 3C). However, gnrh and gnrh receptor gene transcripts were not seen at this developmental stage of EGFP-GnRH neurons.

\section{Effect of Kisspeptin on Apoptosis, Cell Proliferation, and Cytoskeleton-Related Genes Expression in Embryonic EGFP-GnRH Neurons}

To determine whether kisspeptin alter apoptosis, cell proliferation, and cytoskeleton in migrating embryonic EGFP-GnRH neurons, levels of apoptosis, cell proliferation, and cytoskeletonrelated gene expression was determined in migrating embryonic EGFP-GnRH neurons after $12 \mathrm{~h}$ exposure to kisspeptin. Apoptosis-related genes, B-cell lymphoma ( $b c l)$ 2, glucuronidase, Beta (gusB), cysteine-aspartic proteases, or cysteine-dependent
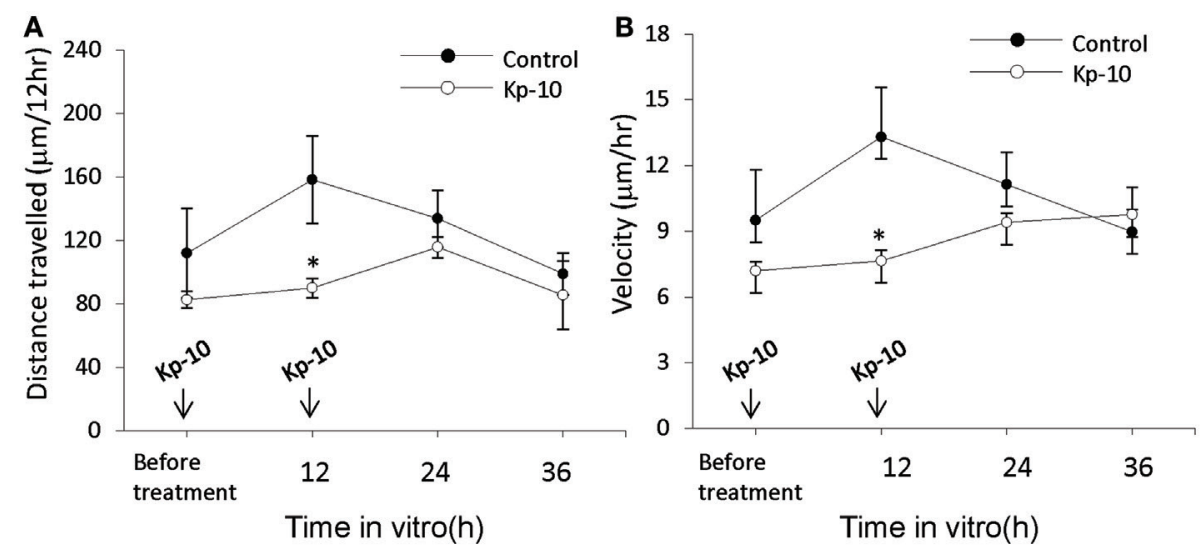

FIGURE 2 | Time-lapse imaging analysis of the enhanced green fluorescent protein (EGFP)-gonadotropin-releasing hormone (GnRH) neurons in brain tissue cultures from embryonic day 14. Total distance traveled ( $\mu \mathrm{m} / 12 \mathrm{~h}) \mathbf{( A )}$ and average rate of movement ( $\mu \mathrm{m} / \mathrm{h})(\mathbf{B})$ [control, $n=7-10$ cells/time point; Kisspeptin-10 (Kp-10), $n=7-10$ cells/time point] determined across the 36 h culture duration. Data are represented by the mean \pm SEM for each group. ${ }^{*} p<0.05$ compared to control group. 


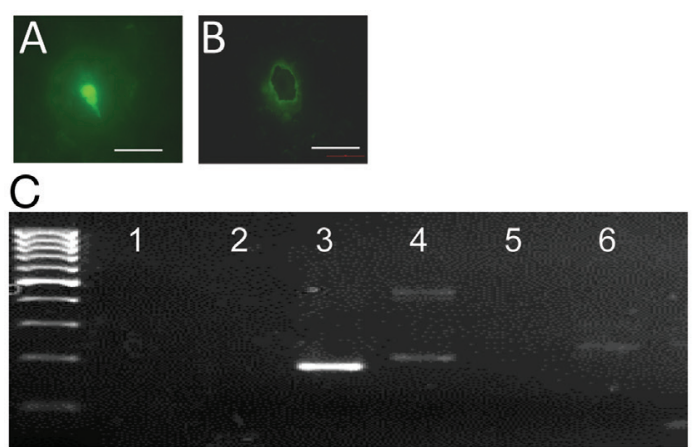

FIGURE 3 | G-protein-coupled receptor 54 (GPR54) mRNA expression in laser-captured enhanced green fluorescent protein (EGFP)gonadotropin-releasing hormone $(\mathrm{GnRH})$ neurons in brain tissue cultures from embryonic day 14. (A) Photographs of EGFP-GnRH neurons in brain tissue culture from embryonic before and (B) after laser capture. Scale bar $=50 \mu \mathrm{m}$. (C) Composite gel showing amplicons of $\mathrm{GnRH}$ (105 bp, lane 2), EGFP (179 bp, lane 3), cyclophiline (199 bp, lane 4), GnRH receptor (100 bp, lane 5), GPR54 (235 bp, lane 6) in laser-captured microdissected $\mathrm{GnRH}$ neurons, and non-template controls (NTC, lane 1) Marker, DNA 100-bp ladder.

aspartate-directed proteases (caspase) 2 and 9 were selected to measure the mRNA levels in laser-captured GnRH neurons from E14 brain slice culture. There was no difference in the expression of these genes between control and exposure to kisspeptin (Figure 4). On the other hand, cell proliferation and cytoskeleton-related genes, gnrh, tubulin $\alpha 1$ (to1), prefolding 6 ( $p f d n)$, kinetin family (kif), sorting nexin18 ( $n n x)$ matrix metalloproteinase (mmp)-9, doublecortin $(d c x)$, and ankyrin repeat domain-containing protein (ankrd) 26 genes were selected to measure their mRNA levels in laser-captured GnRH neurons from E14 brain slice culture. There was no difference in the level of expression of these genes between control and kisspeptin exposed neurons (Figure 5). However, the expression of ankrd26 mRNA was upregulated by exposure to kisspeptin in laser-captured GnRH neurons from E14 brain slice culture [control: $1.0 \pm 0.21$, kisspeptin: $2.41 \pm 0.57 ; t(11)=-2.34$, $p<0.05$ ] (Figure 5).

\section{DISCUSSION}

In this study, real-time imaging and capturing of live EGFP-GnRH neurons from E14 brain slice cultures facilitated time-lapse analysis and characterization of embryonic GnRH neuronal movement following exposure to kisspeptin. Kisspeptin decreased $\mathrm{GnRH}$ neuronal movement in brain slices and increase ankrd26 gene expression in laser-captured GnRH neurons but had no effect on apoptosis and cell proliferation-related genes. These data suggest that exposure to kisspeptin may inhibit GnRH neuronal movement through novel intracellular ankrd26 signaling.

\section{Effects of Kisspeptin on GnRH Neuronal Movement and Gene Expression in the Brain}

Time-lapse image analysis of rat embryonic E14-GnRH neurons between the nasal and brain compartments showed movement of $\mathrm{GnRH}$ neurons at a velocity of $9-13 \mu \mathrm{m} / \mathrm{h}$ in brain slice cultures

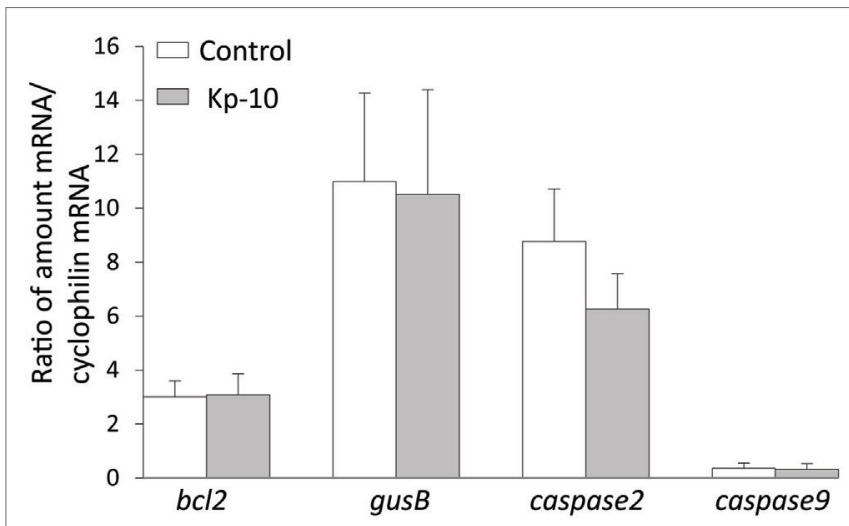

FIGURE 4 | Effects of kisspeptin-10 treatment on apoptosis-related genes expression in laser-captured EGFP-GnRH in brain tissue culture from embryonic (E) day 14. Data are presented as the mean \pm SEM [control: $N=20-25$ cells/animals $(n=6)$, kisspeptin-10 (Kp-10): $N=20-25$ cells/animals $(n=6)]$. bcl2, B-cell lymphoma 2; gusB, glucuronidase; Beta, caspase 2/9, cysteine-aspartic proteases or cysteine-dependent aspartate-directed proteases 2/9.

similar to E13 GnRH neurons in embryonic mouse nasal explants culture migrating at a velocity of $12-13 \mu \mathrm{m} / \mathrm{h}(38)$. On the other hand, our recent time-lapse imaging study of rat $\mathrm{GnRH}$ neurons on postnatal day 0 and day 5 showed movement of $\mathrm{GnRH}$ neurons at a velocity of $3-5 \mu \mathrm{m} / \mathrm{h}$ (39). This suggests that rat embryonic GnRH neurons have high motility and, therefore, may be a good model to determine intracellular signaling for cellular movement. Exposure to kisspeptin reduced the distance traveled and velocity of embryonic GnRH neurons after $12 \mathrm{~h}$ but not after $24 \mathrm{~h}$ of treatment. Percentage of GPR54-expressing $\mathrm{GnRH}$ neurons dramatically is increased during E14.5-16.5 in mice (21). This suggests kisspeptin-GPR54 signaling directly exerts an acute but transient effect on the movement of $\mathrm{GnRH}$ neurons during early development. Several inhibitory signaling such as GABA in GnRH migration are identified $(14,40)$, kisspeptin-GPR54 singling may involve in slow down or halt GnRH migration for fine-tuning of GnRH development. During embryonic stage E14-18, multiple signal transduction pathways are engaged to modulate $\mathrm{GnRH}$ neuronal movement $(38,41)$. Although the mechanism of kisspeptin-GPR54 in suppressing metastasis is still incompletely characterized, previous research has shown kisspeptin-10 as an anti-metastatic agent through complex cellular signaling including loss of intracellular adhesion, stromal invasion, and attachment at distant sites in several types of cancer cells $(30,42-49)$. A recent study reported that kisspeptin-10 affects invasion via modulation of MMP 9 activity in breast cancer cells (50). However, kisspeptin-10 does not affect the expression of MMP9 gene expression in migrating embryonic GnRH neurons in brain slice cultures. Therefore, the effects of kisspeptin-10 on migrating GnRH neurons might involve a different mechanism. A metastasis-associated protein family (MTA) has been identified to promote tumor cell invasion and metastasis in human brain glioma (49). Recent evidence proposes that GPR54 is expressed in hypoxic areas and endothelial cells of tumor blood vessels of glioblastoma (51). Thus, it is possible that 


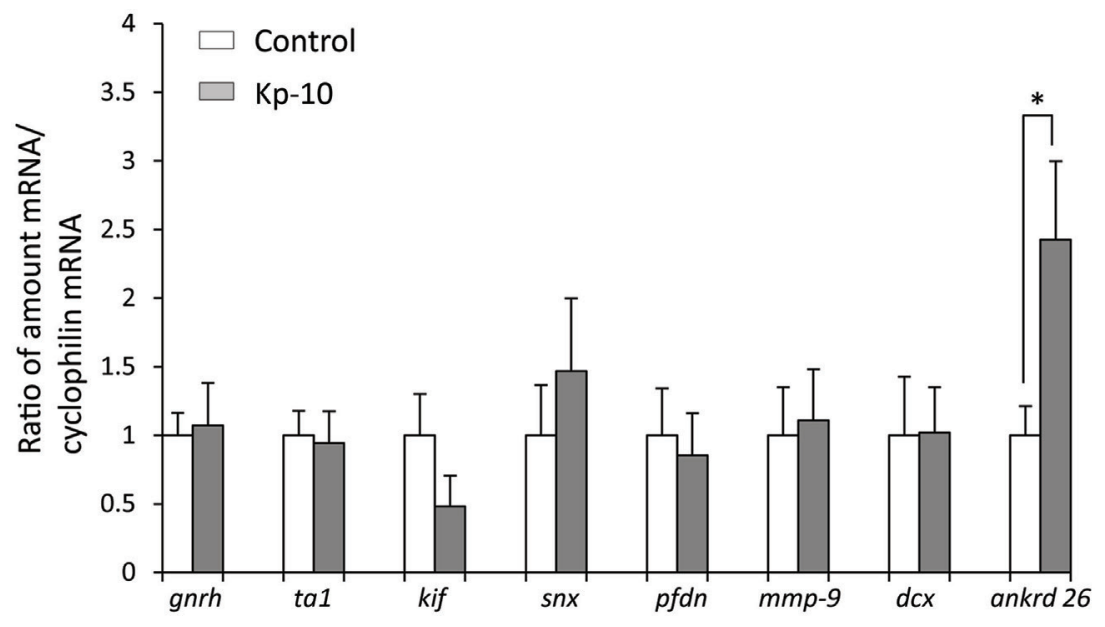

FIGURE 5 | Effects of kisspeptin-10 treatment on cell proliferation and cytoskeleton-related genes expression in laser-captured EGFP-GnRH in brain tissue culture from embryonic day 14. Data are presented as the mean \pm SEM [control, $N=20-25$ cells/animals ( $n=6$ ); kisspeptin (Kp-10), $N=20-25$ cells/ animals $(n=6)]$. ${ }^{*} p<0.05$ compared between Kisspeptin-10 (1 nM) and control group. gnrh, gonadotropin-releasing hormone; ta1, tubulin a1; kif, kinetin family; snx, sorting nexin18; pfdn, prefolding 6; mmp-9, matrix metalloproteinase; dcx, doublecortin; ankrd 26, ankyrin repeat domain-containing protein 26.

kisspeptin-10 may be involved in neuronal or glia specific cellular mechanism of metastasis via a novel molecule such as MTA. In our study, kisspeptin-10 had no effect on apoptosis genes ( $b c l 2$, gusB, caspase 2 and 9) and cell proliferation and cytoskeleton

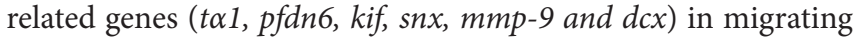
embryonic GnRH neurons. Kisspeptin-10 exposure may affect factors related migrating during developmental stage but not apoptosis.

\section{Effect of Kisspeptin-10 Treatment on Ankrd 26 Signaling}

Kisspeptin-10 treatment increased ankrd $26 \mathrm{mRNA}$ levels and inhibited the movement/migration of EGFP-GnRH neurons in embryonic brain slice cultures. In our previous study, we identified ANKRD protein coding gene expression in laser capture GnRH neurons from E14 and postnatal day 5 (P5) brains through a microarray analysis (52). The levels of ankrd $26 \mathrm{mRNA}$ was higher in $\mathrm{p} 5$ than, the highly motile and migrating E14 stage GnRH neurons. Therefore, cellular ankrd 26 signaling may be involved in the anti-migration process in neurons. Ankyrin repeat is a key amino acid motif as a scaffold for protein-protein interactions $(53,54)$, thus ankyrin repeat mediated proteinprotein interactions may ultimately help to unravel complex cell signaling mechanisms related to the migration process in neurons. Interestingly, ankrd 26 gene belongs to the POTE family of genes that are highly expressed in the prostate, ovary, testis, and placenta of cancer patients (55), which also express kisspeptin and GPR54. This suggests that ankrd 26 gene expression in reproductive organs may be regulated by kisspeptionGPR54 signaling. Retinoic acid receptor responder (RARRES1) is a putative tumor suppressor (56) gene that suppress invasion and colony-forming ability of prostate cancer cells (57). Since, knockdown of RARRES1 gene upregulates ANKRD 26 protein
(56), it would be important to see if kisspeptin regulates ankrd 26 through RARRES1-mediated pathway in neuronal migration. ankrd 26 gene expression is reported in the hypothalamus area, and it is suggested to involve in obesity and gigantism (58). A little knows about the potential physiological functions of ankrd 26 in the brain during embryonic stage. Further studies are needed to understand the direct action of kisspeptin on ankrd 26 gene expression and the functions in migrating $\mathrm{GnRH}$ neurons.

\section{CONCLUSION}

In this study, exposure to kisspeptin reduced the movement of embryonic EGFP-GnRH neurons in brain slice culture. We found that there was no change in the expression of cell proliferation, cytoskeleton and apoptosis-related genes. However, ankrd 26 gene in migrating embryonic EGFP-GnRH neurons was upregulated by exposure to kisspeptin. These studies support that ankrd 26 signaling plays an unidentified role to regulate neuronal movement mediated by kisspeptin-GPR54 signaling. Therefore, ankrd 26 could be a specific target for elucidating the mechanism for suppressing one of pathway in neuronal metastasis by kisspeptin-GPR54 signaling. Although kisspeptin-GPR54 system in the embryonic brain has only recently been studied, our studies suggest that kisspeptin-GPR54 exerts a part of potential function on embryonic GnRH development.

\section{AUTHOR CONTRIBUTIONS}

Study concept and design: IP and TS; acquisition of data: TS and WL; analysis and interpretation of data: IP, WL, and TS; drafting of the manuscript: WL and TS; statistical analysis: WL and TS; critical revision of manuscript: IP and AK; obtained funding: IP, TS, WL, and AK. 


\section{ACKNOWLEDGMENTS}

The authors would like to thank the Director General of Health Malaysia for his permission to publish this article and the Director of the Institute for Medical Research for his support. This study was supported by Ministry of Health Malaysia, JPP07-034 (to TS, IP, and AK), in part by Monash University TS-10-01, MM-08-07,

\section{REFERENCES}

1. Kotani M, Detheux M, Vandenbogaerde A, Communi D, Vanderwinden JM, Le Poul E, et al. The metastasis suppressor gene KiSS-1 encodes kisspeptins, the natural ligands of the orphan $\mathrm{G}$ protein-coupled receptor GPR54. J Biol Chem (2001) 276:34631-6. doi:10.1074/jbc.M104847200

2. Ohtaki T, Shintani Y, Honda S, Matsumoto H, Hori A, Kanehashi K, et al. Metastasis suppressor gene KiSS-1 encodes peptide ligand of a G-protein-coupled receptor. Nature (2001) 411:613-7. doi:10.1038/35079135

3. Harms JF, Welch DR, Miele ME. KISS1 metastasis suppression and emergent pathways. Clin Exp Metastasis (2003) 20:11-8. doi:10.1023/A:1024062911144

4. Janneau JL, Maldonado-Estrada J, Tachdjian G, Miran I, Motte N, Saulnier $\mathrm{P}$, et al. Transcriptional expression of genes involved in cell invasion and migration by normal and tumoral trophoblast cells. J Clin Endocrinol Metab (2002) 87:5336-9. doi:10.1210/jc.2002-021093

5. Makri A, Pissimissis N, Lembessis P, Polychronakos C, Koutsilieris M. The kisspeptin (KiSS-1)/GPR54 system in cancer biology. Cancer Treat Rev (2008) 34:682-92. doi:10.1016/j.ctrv.2008.05.007

6. Ji K, Ye L, Mason MD, Jiang WG. The Kiss-1/Kiss-1R complex as a negative regulator of cell motility and cancer metastasis (review). Int J Mol Med (2013) 32:747-54. doi:10.3892/ijmm.2013.1472

7. Wray S, Grant P, Gainer H. Evidence that cells expressing luteinizing hormone-releasing hormone mRNA in the mouse are derived from progenitor cells in the olfactory placode. Proc Natl Acad Sci U S A (1989) 86:8132-6. doi:10.1073/pnas.86.20.8132

8. Murakami S, Arai Y. Direct evidence for the migration of LHRH neurons from the nasal region to the forebrain in the chick embryo: a carbocyanine dye analysis. Neurosci Res (1994) 19:331-8. doi:10.1016/0168-0102(94)90046-9

9. Yoshida K, Tobet SA, Crandall JE, Jimenez TP, Schwarting GA. The migration of luteinizing hormone-releasing hormone neurons in the developing rat is associated with a transient, caudal projection of the vomeronasal nerve. J Neurosci (1995) 15:7769-77.

10. Parhar IS. Cell migration and evolutionary significance of GnRH subtypes. Prog Brain Res (2002) 141:3-17. doi:10.1016/S0079-6123(02)41080-1

11. Daikoku S, Koide I. Spatiotemporal appearance of developing LHRH neurons in the rat brain. J Comp Neurol (1998) 393:34-47. doi:10.1002/ (SICI)1096-9861(19980330)393:1<34::AID-CNE4>3.0.CO;2-R

12. Jennes L. Prenatal development of the gonadotropin-releasing hormone-containing systems in rat brain. Brain Res (1989) 482:97-108. doi:10.1016/0006-8993(89)90546-5

13. Schwanzel-Fukuda M, Bick D, Pfaff DW. Luteinizing hormone-releasing hormone (LHRH)-expressing cells do not migrate normally in an inherited hypogonadal (Kallmann) syndrome. Brain Res Mol Brain Res (1989) 6:311-26. doi:10.1016/0169-328X(89)90076-4

14. Wierman ME, Kiseljak-Vassiliades K, Tobet S. Gonadotropin-releasing hormone $(\mathrm{GnRH})$ neuron migration: initiation, maintenance and cessation as critical steps to ensure normal reproductive function. Front Neuroendocrinol (2011) 32:43-52. doi:10.1016/j.yfrne.2010.07.005

15. de Roux N, Genin E, Carel JC, Matsuda F, Chaussain JL, Milgrom E. Hypogonadotropic hypogonadism due to loss of function of the KiSS1-derived peptide receptor GPR54. Proc Natl Acad Sci U S A (2003) 100:10972-6. doi:10.1073/pnas.1834399100

16. Funes S, Hedrick JA, Vassileva G, Markowitz L, Abbondanzo S, Golovko A, et al. The KiSS-1 receptor GPR54 is essential for the development of the murine reproductive system. Biochem Biophys Res Commun (2003) 312:1357-63. doi:10.1016/j.bbrc.2003.11.066
MM-07-08 (to TS and IP) and MAKNA Cancer Research Award 2008 (to WL and IP).

\section{SUPPLEMENTARY MATERIAL}

The Supplementary Material for this article can be found online at http://journal.frontiersin.org/article/10.3389/fendo.2016.00015

17. Seminara SB, Messager S, Chatzidaki EE, Thresher RR, Acierno JS Jr, Shagoury JK, et al. The GPR54 gene as a regulator of puberty. N Engl J Med (2003) 349:1614-27. doi:10.1056/NEJMoa035322

18. Han SK, Gottsch ML, Lee KJ, Popa SM, Smith JT, Jakawich SK, et al. Activation of gonadotropin-releasing hormone neurons by kisspeptin as a neuroendocrine switch for the onset of puberty. JNeurosci (2005) 25:11349-56. doi:10.1523/JNEUROSCI.3328-05.2005

19. Herbison AE, De Tassigny X, Doran J, Colledge WH. Distribution and postnatal development of Gpr54 gene expression in mouse brain and gonadotropin-releasing hormone neurons. Endocrinology (2010) 151:312-21. doi:10.1210/en.2009-0552

20. Knoll JG, Clay CM, Bouma GJ, Henion TR, Schwarting GA, Millar RP, et al. Developmental profile and sexually dimorphic expression of kiss 1 and kiss $1 \mathrm{r}$ in the fetal mouse brain. Front Endocrinol (2013) 4:140. doi:10.3389/fendo.2013.00140

21. Kumar D, Freese M, Drexler D, Hermans-Borgmeyer I, Marquardt A, Boehm U. Murine arcuate nucleus kisspeptin neurons communicate with GnRH neurons in utero. J Neurosci (2014) 34:3756-66. doi:10.1523/ JNEUROSCI.5123-13.2014

22. Kirilov M, Clarkson J, Liu X, Roa J, Campos P, Porteous R, et al. Dependence of fertility on kisspeptin-Gpr54 signaling at the GnRH neuron. Nat Commun (2013) 4:2492. doi:10.1038/ncomms3492

23. Bhattacharya M, Babwah AV. Kisspeptin: beyond the brain. Endocrinology (2015) 156:1218-27. doi:10.1210/en.2014-1915

24. Csabafi K, Jaszberenyi M, Bagosi Z, Liptak N, Telegdy G. Effects of kisspeptin-13 on the hypothalamic-pituitary-adrenal axis, thermoregulation, anxiety and locomotor activity in rats. Behav Brain Res (2013) 241:56-61. doi:10.1016/j.bbr.2012.11.039

25. Tanaka M, Csabafi K, Telegdy G. Neurotransmissions of antidepressant-like effects of kisspeptin-13. Regul Pept (2013) 180:1-4. doi:10.1016/j. regpep.2012.08.017

26. Telegdy G, Adamik A. The action of kisspeptin-13 on passive avoidance learning in mice. Involvement of transmitters. Behav Brain Res (2013) 243:300-5. doi:10.1016/j.bbr.2013.01.016

27. Parhar IS, Ogawa S, Sakuma Y. Laser-captured single digoxigenin-labeled neurons of gonadotropin-releasing hormone types reveal a novel G proteincoupled receptor (Gpr54) during maturation in cichlid fish. Endocrinology (2004) 145:3613-8. doi:10.1210/en.2004-0395

28. Cho SG, Li D, Stafford LJ, Luo J, Rodriguez-Villanueva M, Wang Y, et al. KiSS1 suppresses TNFalpha-induced breast cancer cell invasion via an inhibition of RhoA-mediated NF-kappaB activation. J Cell Biochem (2009) 107:1139-49. doi:10.1002/jcb.22216

29. Olbrich T, Ziegler E, Turk G, Schubert A, Emons G, Grundker C. Kisspeptin-10 inhibits bone-directed migration of GPR54-positive breast cancer cells: evidence for a dose-window effect. Gynecol Oncol (2010) 119:571-8. doi:10.1016/j.ygyno.2010.08.018

30. Francis VA, Abera AB, Matjila M, Millar RP, Katz AA. Kisspeptin regulation of genes involved in cell invasion and angiogenesis in first trimester human trophoblast cells. PLoS One (2014) 9:e99680. doi:10.1371/journal.pone.0099680

31. Becker JA, Mirjolet JF, Bernard J, Burgeon E, Simons MJ, Vassart G, et al. Activation of GPR54 promotes cell cycle arrest and apoptosis of human tumor cells through a specific transcriptional program not shared by other Gq-coupled receptors. Biochem Biophys Res Commun (2005) 326:677-86. doi:10.1016/j.bbrc.2004.11.094

32. Mead EJ, Maguire JJ, Kuc RE, Davenport AP. Kisspeptins: a multifunctional peptide system with a role in reproduction, cancer and the cardiovascular system. Br J Pharmacol (2007) 151:1143-53. doi:10.1038/sj.bjp.0707295 
33. Kato M, Ui-Tei K, Watanabe M, Sakuma Y. Characterization of voltage-gated calcium currents in gonadotropin-releasing hormone neurons tagged with green fluorescent protein in rats. Endocrinology (2003) 144:5118-25. doi:10.1210/en.2003-0213

34. Fueshko S, Wray S. LHRH cells migrate on peripherin fibers in embryonic olfactory explant cultures: an in vitro model for neurophilic neuronal migration. Dev Biol (1994) 166:331-48. doi:10.1006/dbio.1994.1319

35. Bolteus AJ, Garganta C, Bordey A. Assays for measuring extracellular GABA levels and cell migration rate in acute slices. Brain Res Brain Res Protoc (2005) 14:126-34. doi:10.1016/j.brainresprot.2004.12.005

36. Bless EP, Walker HJ, Yu KW, Knoll JG, Moenter SM, Schwarting GA, et al. Live view of gonadotropin-releasing hormone containing neuron migration. Endocrinology (2005) 146:463-8. doi:10.1210/en.2004-0838

37. Soga T, Dalpatadu SL, Wong DW, Parhar IS. Neonatal dexamethasone exposure down-regulates $\mathrm{GnRH}$ expression through the $\mathrm{GnIH}$ pathway in female mice. Neuroscience (2012) 218:56-64. doi:10.1016/j.neuroscience.2012.05.023

38. Tobet SA, Schwarting GA. Minireview: recent progress in gonadotropinreleasing hormone neuronal migration. Endocrinology (2006) 147:1159-65. doi:10.1210/en.2005-1275

39. Lim WL, Soga T, Parhar IS. Maternal dexamethasone exposure inhibits the gonadotropin-releasing hormone neuronal movement in the preoptic area of rat offspring. Dev Neurosci (2014) 36:95-107. doi:10.1159/000360416

40. LeeJM,TiongJ,MaddoxDM,CondieBG,WrayS. Temporalmigration ofgonadotrophin-releasing hormone-1 neurones is modified in GAD67 knockout mice. J Neuroendocrinol (2008) 20:93-103. doi:10.1111/j.1365-2826.2007.01623.x

41. Forni PE, Wray S. GnRH, anosmia and hypogonadotropic hypogonadism - where are we? Front Neuroendocrinol (2015) 36:165-77. doi:10.1016/j. yfrne.2014.09.004

42. Martin TA, Watkins G, Jiang WG. KiSS-1 expression in human breast cancer. Clin Exp Metastasis (2005) 22:503-11. doi:10.1007/s10585-005-4180-0

43. Kang HS, Baba T, Mandai M, Matsumura N, Hamanishi J, Kharma B, et al. GPR54 is a target for suppression of metastasis in endometrial cancer. $\mathrm{Mol}$ Cancer Ther (2011) 10:580-90. doi:10.1158/1535-7163.MCT-10-0763

44. Cvetkovic D, Babwah AV, Bhattacharya M. Kisspeptin/KISS1R system in breast cancer. J Cancer (2013) 4:653-61. doi:10.7150/jca.7626

45. Schmidt E, Haase M, Ziegler E, Emons G, Grundker C. Kisspeptin-10 inhibits stromal-derived factor 1-induced invasion of human endometrial cancer cells. Int J Gynecol Cancer (2014) 24:210-7. doi:10.1097/IGC.0000000000000050

46. Tan K, Cho SG, Luo W, Yi T, Wu X, Siwko S, et al. KiSS1-induced GPR54 signaling inhibits breast cancer cell migration and epithelial-mesenchymal transition via protein kinase D1. Curr Mol Med (2014) 14:652-62. doi:10.217 4/1566524014666140603115314

47. Taylor J, Pampillo M, Bhattacharya M, Babwah AV. Kisspeptin/KISS1R signaling potentiates extravillous trophoblast adhesion to type-I collagen in a PKC- and ERK1/2-dependent manner. Mol Reprod Dev (2014) 81:42-54. doi:10.1002/mrd.22279
48. Savvidis C, Papaoiconomou E, Petraki C, Msaouel P, Koutsilieris M. The role of KISS1/KISS1R system in tumor growth and invasion of differentiated thyroid cancer. Anticancer Res (2015) 35:819-26.

49. Shan S, Hui G, Hou F, Shi H, Zhou G, Yan H, et al. Expression of metastasisassociated protein 3 in human brain glioma related to tumor prognosis. Neurol Sci (2015) 36(10):1799-804. doi:10.1007/s10072-015-2252-8

50. Zajac M, Law J, Cvetkovic DD, Pampillo M, Mccoll L, Pape C, et al. GPR54 (KISS1R) transactivates EGFR to promote breast cancer cell invasiveness. PLoS One (2011) 6:e21599. doi:10.1371/journal.pone.0021599

51. Murat A, Migliavacca E, Hussain SF, Heimberger AB, Desbaillets I, Hamou MF, et al. Modulation of angiogenic and inflammatory response in glioblastoma by hypoxia. PLoS One (2009) 4:e5947. doi:10.1371/journal.pone.0005947

52. Ogawa S, Parhar IS. Expression profiles of olfactory receptor genes in gonadotropin-releasing hormone neurons during migration. (in preparation).

53. Mosavi LK, Cammett TJ, Desrosiers DC, Peng ZY. The ankyrin repeat as molecular architecture for protein recognition. Protein Sci (2004) 13:1435-48. doi:10.1110/ps.03554604

54. Kramer MA, Wetzel SK, Pluckthun A, Mittl PR, Grutter MG. Structural determinants for improved stability of designed ankyrin repeat proteins with a redesigned C-capping module. J Mol Biol (2010) 404:381-91. doi:10.1016/j. jmb.2010.09.023

55. Bera TK, Zimonjic DB, Popescu NC, Sathyanarayana BK, Kumar V, Lee B, et al. POTE, a highly homologous gene family located on numerous chromosomes and expressed in prostate, ovary, testis, placenta, and prostate cancer. Proc Natl Acad Sci U S A (2002) 99:16975-80. doi:10.1073/pnas.262655399

56. Sahab ZJ, Hall MD, Zhang L, Cheema AK, Byers SW. Tumor suppressor RARRES1 REGULATES DLG2, PP2A, VCP, EB1, and Ankrd26. J Cancer (2010) 1:14-22. doi:10.7150/jca.1.14

57. Oldridge EE, Walker HF, Stower MJ, Simms MS, Mann VM, Collins AT, et al. Retinoic acid represses invasion and stem cell phenotype by induction of the metastasis suppressors RARRES1 and LXN. Oncogenesis (2013) 2:e45. doi:10.1038/oncsis.2013.6

58. Bera TK, Liu XF, Yamada M, Gavrilova O, Mezey E, Tessarollo L, et al. A model for obesity and gigantism due to disruption of the Ankrd26 gene. Proc Natl Acad Sci U S A (2008) 105:270-5. doi:10.1073/pnas.0710978105

Conflict of Interest Statement: The authors declare that the research was conducted in the absence of any commercial or financial relationships that could be construed as a potential conflict of interest.

Copyright (C) 2016 Soga, Lim, Khoo and Parhar. This is an open-access article distributed under the terms of the Creative Commons Attribution License (CC BY). The use, distribution or reproduction in other forums is permitted, provided the original author(s) or licensor are credited and that the original publication in this journal is cited, in accordance with accepted academic practice. No use, distribution or reproduction is permitted which does not comply with these terms. 